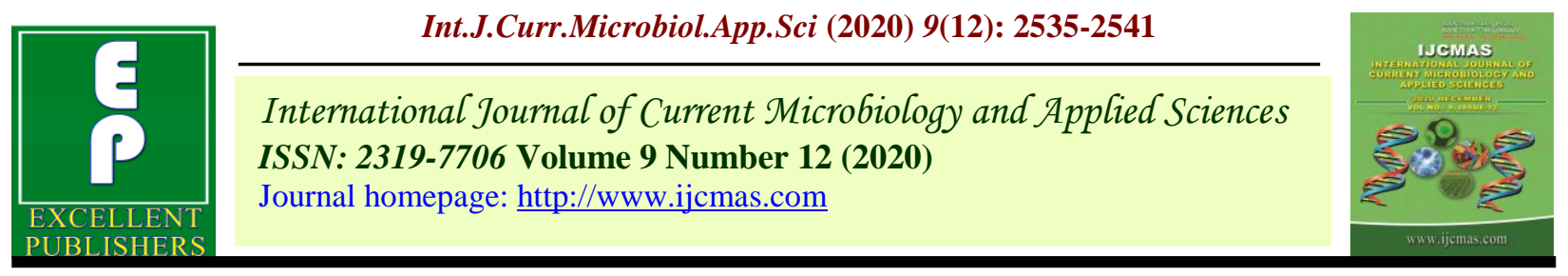

Original Research Article

https://doi.org/10.20546/ijcmas.2020.912.301

\title{
Trend Analysis of Annual Rainfall and Rainy Days Using Mann Kendall Method and Sen's Slope Estimator in Jalgaon District of Maharashtra
}

\author{
Kundan M. Kamble*, V.A. Sthool, S.K. Upadhye, J.D. Jadhav and S.V. Bagade \\ Mahatma Phule Krishi Vidyapeeth, Rahuri, Dist. Ahmednagar, Maharashtra, India \\ *Corresponding author
}

\begin{abstract}
A B S T R A C T
Rainfall occupies an important position in deciding the future planning of the cropping system in any rainfed agriculture. Indian agriculture is predominantly influenced by rainfall, specifically by the south-west monsoon (JuneSeptember). Rainfall trend is an important tool which assesses the impact of climate change and provides direction to cope up with its adverse effect on the agriculture. The Jalgaon district lies in the north-west side of Maharashtra and spreads across the Deccan Plateau in the rain shadow region of the Sahyadri mountain ranges on the northernmost tip of the state of Maharashtra. The present study entitled analysis of daily rainfall data of past years were used to compute annual rainfall and rainy days of fifteen tehsils of Jalgaon district using Mann Kendall method and Sen's slope estimator. Annual rainfall has been increased with increasing rainy days in Erandol and Yavaltehsils Rainfall in Jalgaon, Raver, Bodhwad, and Muktainagar tehsils decreased with decreasing rainy days and rainfall of Amalner, Bhadgaon, Jamner, Pachora and Dharangaon decreased with increasing rainy days.
\end{abstract}

\section{Keywords}

Rainfall trend, Rainy days trend, Mann Kendall method, Sen's slope method

Article Info

Accepted:

18 November 2020

Available Online:

10 December 2020

\section{Introduction}

Agriculture plays an important role in the Indian economy which is located in southern Asia. As Indian agricultural country, small changes in the climatic condition largely affect the country's economy. The changes in the most important climatological parameter i.e. rainfall. Rainfall is the dominant single weather element influencing the intensity and location of the farming system and the choice of enterprise. India is highly influenced by the southwest monsoon. According to Guhathakurta and Rajeevan (2008), although average annual rainfall in the country is 119.4 $\mathrm{cm}$, about $60 \%$ of the country's total cultivable land remains as rainfed. The Maharashtra state is prominently agriculturebased. However, the share of the agriculture sector in the state's gross domestic production is less than $25 \%$. The rainfall received in an area is an important factor in determining the 
amount of water available to meet various demands, such as agricultural, industrial and domestic water supply. The Maharashtra state which is to the northwest of peninsular is facing water scarcity almost every year hence the trend analysis was carried out to examine the long term trends in rainfall over different subdivisions. The rainfall trend is very crucial for better economic development, hydrological planning and adaptation for extreme events.

Considering the above facts, present study is done to find out trends in annual rainfall and rainy days in fifteen tehsils of Jalgaon District.

\section{Materials and Methods}

\section{Study area}

The study area of this research is Jalgaon district lies in the north-west side of Maharashtra between $20^{\circ}$ to $21^{\circ}$ north latitude and $74^{\circ} 55^{\prime}$ to $76^{\circ} 28^{\prime}$ east longitude and spreads across the Deccan Plateau in the rain shadow region of the Sahyadri mountain ranges on the northernmost tip of the state of Maharashtra. The state of Madhya Pradesh lies to the north, the Buldhana district of Maharashtra to the east, the Aurangabad district of Maharashtra to south, Dhule and Nashik districts of Maharashtra to the west. To the north, we have the Satpura ranges and the river Aner goes from the northern part which forms the natural boundaries to the district. Tapiriver in the central part of the district also covers a large area with its tributaries which are the main river of the district. There are 15 tahasils in Jalgaon district viz., (1) Jalgaon (2) Jamner (3) Chalisgaon (4) Dhargaon (5) Bhusawal (6) Bodhwad (7) Yawal (8) Raver (9) Muktainagar (10) Amalner (11) Chopada (12) Pachora (13) Erandol (14) Bhadgaon and (15) Parola (Table 1).

\section{Data collection}

The daily rainfall data of all Tehsils in Jalgaon district are collected from (1) Department of Agricultural Meteorology, College of Agriculture, Pune (2) State Agriculture Department, Pune (3) India Meteorological Department, Pune and (4) Downloaded from www.maharain.gov.in (www.krishi.maharashtra.gov.in) from January to December.

\section{Software used for study}

Microsoft office sub-module MS-Excel was used for data analysis. The formulation and conditional statements were also executed in MS-Excel. The Weather Cock software developed by CRIDA, Hyderabad was used for the analysis of weather parameters, viz., annual mean, standard deviation, coefficient of variation of rainfall and rainy days. MAKESEN'S excel template was used for trend detection and estimation of the magnitude of trend (Salmi et al., 2002).

\section{Rainfall and rainy days trend analysis}

Trend analysis (increase or decrease) of all the independent weather parameters (e.g. annual rainfall and rainy days) was statistically examined by the non-parametric Mann-Kendall test and Sen's slope method (Choudhury et al., 2012).

\section{Mann-kendall test}

Compare first-year data point with $2^{\text {nd }}$, $3^{\text {rd }}, \ldots \ldots, 58^{\text {th }}$-year data point.

Assign,

+1 if $\mathrm{X} 1<\mathrm{X} 2$

-1 if $\mathrm{X} 1>\mathrm{X} 2$

0 if $\mathrm{X} 1=\mathrm{X} 2$

The Sum of assigned values will give MannKendall Statistic (S). 
A very high value of Mann-Kendall Statistic is an indicator of an increasing trend and a very low negative value indicated a decreasing trend. However, it is necessary to compute the probability associated with Mann-Kendall Statistic and the sample size, $\mathrm{n}$, to statistically quantify the significance of the trend. The Mann-Kendall test statistics is calculated using the formula,

$\mathrm{S}=\sum_{\mathrm{k}-1}^{\mathrm{n}} \sum_{\mathrm{j}-\mathrm{k}-1}^{\mathrm{n}} \operatorname{sign}(\mathrm{Xj}-\mathrm{Xk})$

Where,

$\mathrm{X}_{\mathrm{j}}$ and $\mathrm{X}_{\mathrm{k}}$ are the annual values in years $\mathrm{j}$ and $\mathrm{k}, \mathrm{j}>\mathrm{k}$ respectively,

$\mathrm{X}_{\mathrm{k}}$ represents the data point at time $\mathrm{k}$.

The value of sign $\left(\mathrm{x}_{\mathrm{j}}-\mathrm{x}_{\mathrm{k}}\right)$ is computed as the number follows:

1 if $x_{j}-x_{k}>0$

0 if $x_{j}-x_{k}=0$

-1 if $x_{j}-x_{k}<0$

This statistic represents the number of positive differences minus the number of negative differences for all the differences considered. For large samples $(N>10)$, the test is conducted using a normal approximation $(\mathrm{Z}$ statistics) with the mean and the variance as follows:

Variance $(S)=$

$\frac{\left(n(n-1)(2 n+5)-\sum_{p=1}^{p=g}(t p(t p-1)(2 t p+5))\right.}{18}$

Where,

$\mathrm{n}=$ number of years,

$\mathrm{g}=$ number of tied groups

(A tied group is a set of sample data having the same value.)

tp $=$ number of items in the tied group

Calculate a normalized test statistic $\mathrm{Z}$ by the following equation,

$\mathrm{z}=\frac{(\mathrm{S}+1)}{\sqrt{\text { Varience }(S)} \quad \text { If } \mathrm{S}>0}$ $\mathrm{z}=0 \quad$ If $\quad \mathrm{S}=0$
$\mathrm{z}=\frac{(\mathrm{s}-1)}{\sqrt{\text { Varience }(S)}} \quad$ If $\mathrm{S}<0$

Where, $\quad \mathrm{S}=\mathrm{p}-\mathrm{q}$

$\mathrm{p}=$ number of $(+1)$ values and

$\mathrm{q}=$ number of $(-1)$ values

The presence of a statistically significant trend is evaluated using the $\mathrm{Z}$ value. A positive value of $\mathrm{Z}$ indicates an upward trend and its negative value a downward trend. The statistic $\mathrm{Z}$ has a normal distribution. In the present study, at a confidence level of 99, 95, and 90 per cent the positive or negative trends are determined by the test statistic.

\section{Sen's slope method}

Sen's slope method was used for predicting the magnitude of hydro-meteorological time series data. This method uses a linear model for the trend analysis by using a simple nonparametric procedure developed by Sen (1968).

To derive an estimate of the slope $Q_{t}$, the slope of all data pairs is calculated by

$\mathrm{Q}_{\mathrm{t}}=^{\frac{x_{j}-X k}{j-k}}, \mathrm{i}=1,2,3, \mathrm{~N}, \mathrm{j}>\mathrm{k}$

Where, $x_{j}$ and $x_{k}$ are the data values for $j$ and $k$ times of a period and $j>k$.

The slope is estimated for each observation. If there are ' $n$ ' values of $X_{j}$ in the time series then as many as $\mathrm{N}=\mathrm{n}(\mathrm{n}-1) / 2$ slope estimates, $\mathrm{Q}_{\mathrm{t}}$ is to be computed. The Sen's estimator of the slope is the median of these $\mathrm{N}$ values of $Q_{t}$. The $N$ values of $Q_{t}$ are ranked from the smallest to the largest and the Sen's estimate is calculated as, 
$Q_{t}= \begin{cases}Q \frac{N+1}{2} & \text { If } N \text { is odd } \\ \frac{1}{2}\left(Q \frac{N}{2}+Q \frac{N+2}{2}\right. & \text { If } N \text { is even }\end{cases}$

The median of all slope values gives $\mathrm{Q}$, which is the magnitude of a trend. A positive value indicates increasing and negative values indicate a decreasing trend of rainfall and rainy days.

\section{Results and Discussion}

\section{Trends in annual rainfall}

The annual rainfall data for the period of 1961 to 2018 except Bodhwada, dharangaon and Muktainager tehsils from 1998 to 2018 is analysed using Mann Kendall test method and Sen's slope estimation method and results are given in table 2. Out of fifteen tehsils, the annual rainfall at Parola is increasing at 99 per cent significance level, Bodhwad and
Muktainagar are decreasing at 95 per cent significant level and Pachora is decreasing at 90 per cent of significance level. There was no significant trend observed in annual rainfall of remaining tehsils of Jalgaon district.

From table 2 it is also observed that the value of Mann Kendall test Z and Sen's slope estimate $Q$ of 1) Amalner, Bhadgaon, Dhrangaon, Jalgaon, Jamner and Muktainagar is negative and 2) Bhusaval, Chalisgaon, Chopda and Erandol is positive. It indicates decreasing and increasing trend respectively even though it is statistically not significant (Fig. 1).

\section{Trends in rainy days}

Rainy days data shows that the trend in rainy days is increasing in Erandol tehsil at 95 per cent significance (Fig. 2).

Table.1 Geographical location and availability of data for study area

\begin{tabular}{|c|c|c|c|c|c|c|c|}
\hline \multirow{2}{*}{$\begin{array}{l}\text { Sr. } \\
\text { No. }\end{array}$} & \multirow{2}{*}{$\begin{array}{c}\text { Location of } \\
\text { Raingauge } \\
\text { Station }\end{array}$} & \multirow{2}{*}{$\begin{array}{r}\text { Geographical } \\
\text { area }\left(\mathrm{Km}^{2}\right)\end{array}$} & \multirow[t]{2}{*}{ Latitude } & \multirow[t]{2}{*}{ Longitude } & \multicolumn{2}{|c|}{ Period (year) } & \multirow[b]{2}{*}{$\begin{array}{l}\text { No. of } \\
\text { years }\end{array}$} \\
\hline & & & & & From & To & \\
\hline 1) & Amalner & 783.31 & $21^{\circ} 05^{\prime} \mathrm{N}$ & $75^{\circ} 09^{\prime} \mathrm{E}$ & 1961 & 2018 & 58 \\
\hline 2) & Bhadgaon & 443.07 & $21^{\circ} 40^{\prime} \mathrm{N}$ & $74^{\circ} 05^{\prime} \mathrm{E}$ & 1961 & 2018 & 58 \\
\hline 3) & Bhusaval & 440.05 & $21^{\circ} 04^{\prime} \mathrm{N}$ & $75^{\circ} 45^{\prime} \mathrm{E}$ & 1961 & 2018 & 58 \\
\hline 4) & Bodhwad & 372.31 & $20^{\circ} 09^{\prime} \mathrm{N}$ & $76^{\circ} 01^{\prime} \mathrm{E}$ & 1998 & 2018 & 21 \\
\hline 5) & Chalisgaon & 1192.33 & $20^{\circ} 33^{\prime} \mathrm{N}$ & $75^{\circ} 10^{\prime} \mathrm{E}$ & 1961 & 2018 & 58 \\
\hline 6) & Chopda & 1147.58 & $21^{\circ} 15^{\prime} \mathrm{N}$ & $75^{\circ} 18^{\prime} \mathrm{E}$ & 1961 & 2018 & 58 \\
\hline 7) & Dharangaon & 497.21 & $21^{\circ} 01^{\prime} \mathrm{N}$ & $75^{\circ} 16^{\prime} \mathrm{E}$ & 1998 & 2018 & 21 \\
\hline 8) & Erandol & 509.99 & $20^{\circ} 54^{\prime} \mathrm{N}$ & $75^{\circ} 23^{\prime} \mathrm{E}$ & 1961 & 2018 & 58 \\
\hline 9) & Jalgaon & 11765.00 & $21^{\circ} 00^{\prime} \mathrm{N}$ & $75^{\circ} 45^{\prime} \mathrm{E}$ & 1961 & 2018 & 58 \\
\hline 10) & Jamner & 1308.94 & $20^{\circ} 47^{\prime} \mathrm{N}$ & $75^{\circ} 47^{\prime} \mathrm{E}$ & 1961 & 2018 & 58 \\
\hline 11) & Muktainager & 497.21 & $21^{\circ} 01^{\prime} \mathrm{N}$ & $75^{\circ} 16^{\prime} \mathrm{E}$ & 1998 & 2018 & 21 \\
\hline 12) & Pachora & 807.74 & $20^{\circ} 42^{\prime} \mathrm{N}$ & $75^{\circ} 29^{\prime} \mathrm{E}$ & 1961 & 2018 & 58 \\
\hline 13) & Parola & 780.00 & $20^{\circ} 53^{\prime} \mathrm{N}$ & $75^{\circ} 07^{\prime} \mathrm{E}$ & 1961 & 2018 & 58 \\
\hline 14) & Raver & 906.09 & $21^{\circ} 15^{\prime} \mathrm{N}$ & $7^{\circ} 02^{\prime} \mathrm{E}$ & 1961 & 2018 & 58 \\
\hline 15) & Yaval & 891.96 & $21^{\circ} 10^{\prime} \mathrm{N}$ & $75^{\circ} 42^{\prime} \mathrm{E}$ & 1961 & 2018 & 58 \\
\hline
\end{tabular}


Table.2 Annual rainfall and rainy days trend analysis of all tehsils of Jalgaon District

\begin{tabular}{|c|c|c|c|c|c|c|c|c|c|}
\hline \multirow{2}{*}{$\begin{array}{l}\text { Time } \\
\text { series }\end{array}$} & \multirow{2}{*}{$\begin{array}{l}\text { First } \\
\text { year }\end{array}$} & \multirow{2}{*}{$\begin{array}{l}\text { Last } \\
\text { Year }\end{array}$} & \multirow[t]{2}{*}{$\mathbf{N}$} & \multicolumn{3}{|c|}{ Rainfall (mm) } & \multicolumn{3}{|c|}{ Rainy days } \\
\hline & & & & Test $\mathrm{Z}$ & Signific. & $\mathbf{Q}$ & Test $Z$ & Signific. & $\mathbf{Q}$ \\
\hline Amalner & 1961 & 2018 & 58 & -1.13 & & -1.926 & 0.74 & & 06 \\
\hline Bhadgaon & 1961 & 2018 & 58 & -0.95 & & -1.707 & 0.62 & & 04 \\
\hline Bhusaval & 1961 & 2018 & 58 & 09 & & 0.12 & 0.74 & & 06 \\
\hline Bodhwad & 1998 & 2018 & 21 & -1.96 & $*$ & -16.32 & -1.24 & & -0.57 \\
\hline Chalisgaon & 1961 & 2018 & 58 & 09 & & 0.122 & 0.46 & & 04 \\
\hline Chopda & 1961 & 2018 & 58 & 0.87 & & 1.622 & -0.13 & & 0 \\
\hline Dharangaon & 1998 & 2018 & 21 & -1.12 & & -11.12 & -1.36 & & -0.63 \\
\hline Erandol & 1961 & 2018 & 58 & 1.60 & & 2.402 & 2.42 & $*$ & 0.17 \\
\hline Jalgaon & 1961 & 2018 & 58 & -1.24 & & -1.903 & -0.82 & & -07 \\
\hline Jamner & 1961 & 2018 & 58 & -1.21 & & -2.70 & 0.05 & & 0 \\
\hline Muktainagar & 1998 & 2018 & 21 & -2.33 & * & -15.10 & -0.15 & & 0 \\
\hline Pachora & 1961 & 2018 & 58 & -1.79 & + & -3.14 & 0.67 & & 0.04 \\
\hline Parola & 1961 & 2018 & 58 & 2.91 & $* *$ & 3.56 & -0.28 & & 0 \\
\hline Raver & 1961 & 2018 & 58 & -1.52 & & -2.74 & -1.44 & & -0.13 \\
\hline Yaval & 1961 & 2018 & 58 & 1.01 & & 1.812 & 0.69 & & 0.05 \\
\hline
\end{tabular}

* Significance at 95 per cent confidence level, $* *$ Significance at a 99 per cent confidence level and

+ Significance at 90per cent confidence level

Fig.1 Method wise analysis of annual rainfall trend

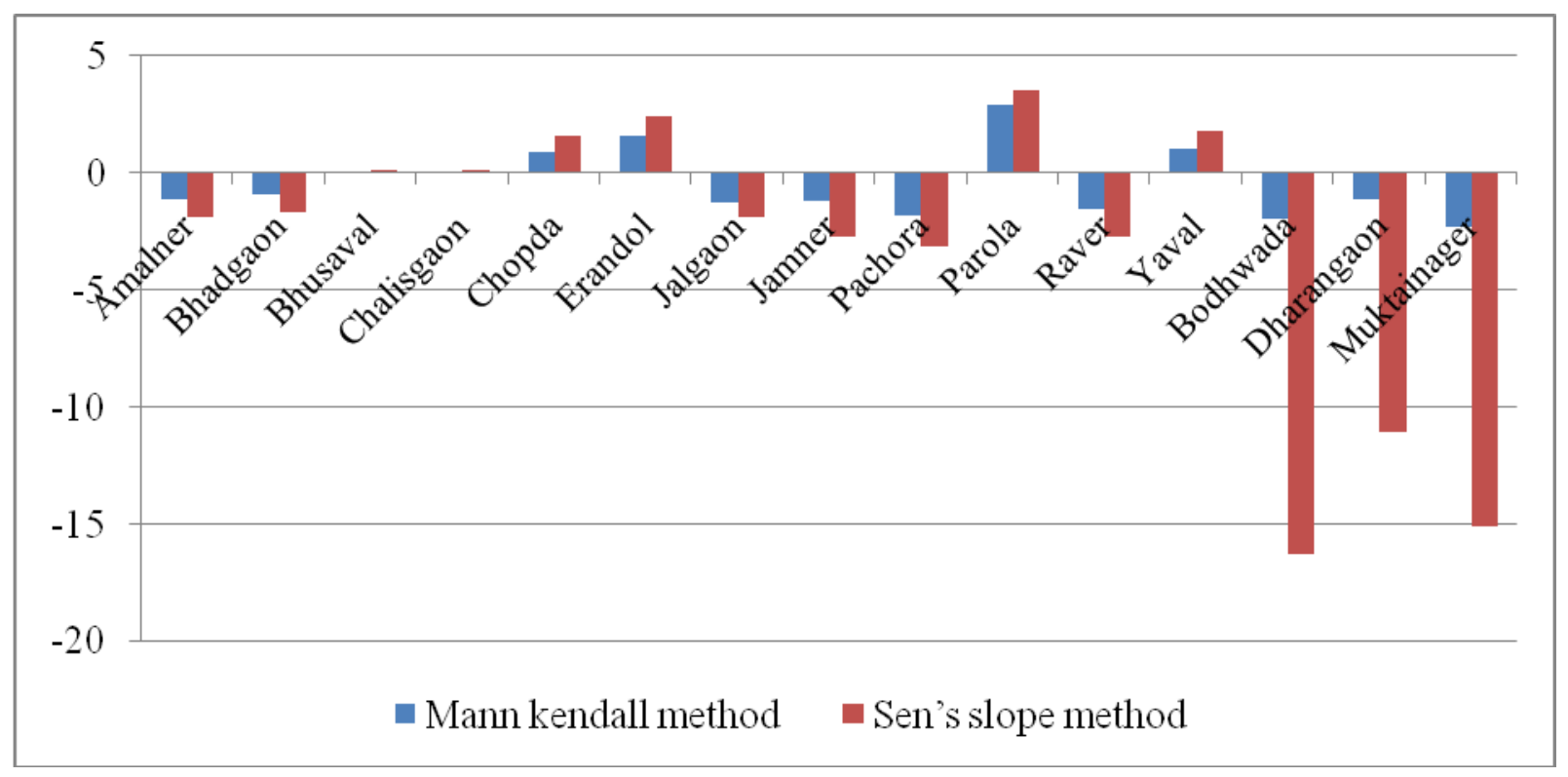


Fig.2 Method wise analysis of annual rainy days trend

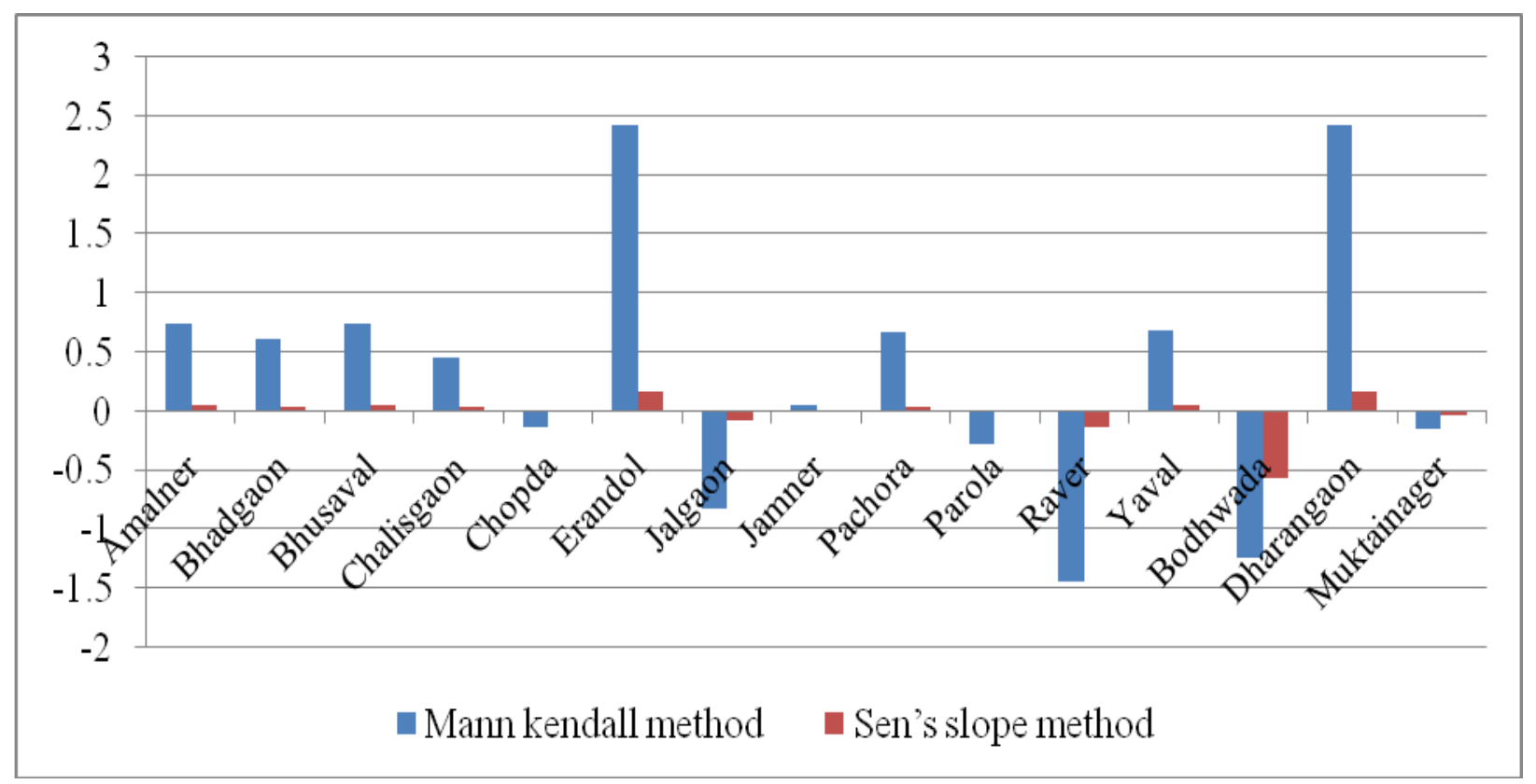

From the table 2 it is also observed that the value of Mann Kendall test $Z$ and Sen's slope estimate $Q$ for rainy days of Amalner, Bhadgaon, Bhusaval, Chalisgaon, Pachora and Yavalare positive it indicates increasing trend in rainy days even though it is statistically not significant. The value of Mann Kendall test $Z$ and Sen's slope estimate Q for rainy days of Bodhwad, Dharangaon, Jalgaon and Raver are negative. It indicates decreasing trend in rainy days even though it is statisticaly not significant.

There was no trend observed in Chopda, Jamner, Muktainagar and Parola

Hence concluded, by using the Mann Kendall test and Sen's slope method trend in rainfall and rainy days were determined which is useful for determining the increasing or decreasing trends and it's magnitude in annual rainfall and rainy days. Annual rainfall has been increased with increasing rainy days inErandol and Yaval tehsils Rainfall in Jalgaon, Raver, Bodhwad, and Muktainagar tehsils decreased with decreasing rainy days and rainfall of Amalner, Bhadgaon, Jamner, Pachora and Dharangaon decreased with increasing rainy days.

\section{Acknowledgement}

The authors are thankful to the Department of Agricultural Meteorology, College of Agriculture, Pune, for their support, the mahaagri and IMD for providing the data. This work would not have been possible without the support and guidance of Dr. J. D. Jadhav Head Department of Agril. Meteorology College of Agriculture, Pune for their valuable insight and analysis.

Author Contributions: All authors equally contributed

Author statement: All authors read, reviewed, agreed and approved the final manuscript

\section{Study area}

Jalgaon district of Maharashtra, India 


\section{References}

Barakade, A.J. 2014. Rainfall trend in drought prone region in eastern part of Satara district of Maharashtra, India. Eur. Acad. Res (2): 329-340.

Deulkar, A. M., Dixit, P. R. and Kulkarni, H. 2015. Trends in rainfall pattern over Vidarbha region of Maharashtra state, India. Internat. J. Modern Trends In Engg. and Res. 2(7): 700-70.

Girma E, Tino J, Wayessa G. Rainfall trend and variability analysis in Setema Gatira area of Jimma, South western Ethiopia. African Journal of Agricultural Research .2016; 11:3037 3045 .

Guhathakurta P, Rajeevan M. Trends in the rainfall pattern over India. NCC Research Report No 2/2006, Indian Meteorological Department, 2006, 23.

Jain SK, Kumar V. Trend analysis of rainfall and temperature data for India. Current Science $.2012 ; 102(1): 37$-49.

Joshi, J. K. 2019. Rainfall analysis for crop management planning for Solapur district. M.Sc. (Agri.) thesis submitted to Mahatma Phule Krishi Vidyapeeth, Rahuri, India.

Mondal, A. 2012. Rainfall trend analysis by Mann-Kendall Test: a case study of northern eastern part of Cuttack district,
Orissa. International Journal of Geology, Earth and Environmental Science. 87: 2277-2280.

Sen PK. Estimation of regression coefficient based on Kendall's test. Journal of American Statistical Association .1968; 63:1379 -1389.

Tayade, P. P. 2019. Studies on rainfall variation in Sangli district of Maharashtra for analysis of drought and extreme events. M.Sc. (Agri.) thesis submitted to Mahatma Phule Krishi Vidyapeeth, Rahuri, India.

Upadhye, S. K., Taley, S. M., Karunakar ,A. N. and Jadhav, K. A. 2016. Trends in rainfall and rainy days of Akola in Vidarbha region. Proceeding of $3^{\text {rd }}$ National Conference on Water, Environment and Society (NCWES):342-34.

Wale VD. Studies on rainfall variations in Sangli district of Maharashtra for analysis of drought and extreme events. M.Sc. thesis submitted to, Mahatma Phule Krishi Vidyapeeth, Rahuri , 2019

Zende, A. M., Nagarajan, R. and Atal, K. R. 2017. Rainfall Trend In Semi Arid Region-Yerala River Basin, Western Maharashtra, India, Internat. J. Advancement in Technol. 3(3):137-145.

\section{How to cite this article:}

Kundan M. Kamble, V.A. Sthool, S.K. Upadhye, J.D. Jadhav and Bagade, S.V. 2020. Trend Analysis of Annual Rainfall and Rainy Days Using Mann Kendall Method and Sen's Slope Estimator in Jalgaon District of Maharashtra. Int.J.Curr.Microbiol.App.Sci. 9(12): 2535-2541. doi: https://doi.org/10.20546/ijcmas.2020.912.301 